\title{
Paradoxical effect of ethanol on liver lipogenesis in the genetically-obese Zucker rat
}

\author{
BY C. KARSENTY, M. ULMER*, F. CHANUSSOT, \\ R. RATANASAVANH† AND G. DEBRY \\ Département de Nutrition et des Maladies Métaboliques de l'Université de Nancy I et \\ Unité de Recherches de Nutrition et Diététique de l'INSERM U. 59, \\ 40 rue Lionnois, F-54000 Nancy, France
}

(Received 4 April 1984 - Accepted 17 September 1984)

\begin{abstract}
1. Sixteen obese $(f a / f a)$ Zucker rats, sixteen lean $(\mathrm{Fa} /-)$ Zucker rats and sixteen Wistar rats, all male rats aged 7-8 weeks, were given either a control (C) diet containing no ethanol or an ethanol (E) diet in which $36 \%$ of the energy was supplied by ethanol, for a period of 4 weeks.

2. The activities of glucose-6-phosphate dehydrogenase $(E C 1.1 .1 .49)$, glucose-6-phosphatase $(E C$ 3.1.3.9) and glycerol kinase $(E C 2$.7 1. 13) and the glycogen content in the livers of obese $(f a / f a)$ rats were lower in animals given diet $\mathrm{E}$ than in those given diet $\mathrm{C}$. As a result, hepatic lipogenesis and fatty degeneration of the liver were reduced in obese $(f a / f a)$ rats given diet $\mathrm{E}$.
\end{abstract}

Chronic alcohol intoxication of the genetically-obese $(f a / f a)$ Zucker rat does not affect the degree of obesity or its hyperlipidaemia. Paradoxically, however, such intoxication results in less fatty degeneration of the liver than is found in control animals (Karsenty et al. 1985). To improve our understanding of this latter phenomenon, we have studied hepatic lipogenesis, which is one factor in the development of fatty infiltration of the liver.

\section{MATERIALS AND METHODS}

\section{Animal trials}

Sixteen Wistar rats (CESAL-Vigneul-sous-Montmédy) and sixteen obese $(f a / f a)$ and sixteen non-obese ( $\mathrm{Fa} /$-) Zucker rats (CNRS-Orléans-la-Source), all male rats aged 7-8 weeks, were divided into six groups of eight rats. Each group was allowed free access to a diet containing ethanol (diet E; $36 \%$ of total energy from ethanol) or a control, alcohol-free diet (diet C). Details of diet composition and animal housing have been described elsewhere (Karsenty et al. 1985).

At the end of the 4th week, blood samples were obtained by abdominal aortic puncture for plasma enzyme activity assays. One rat from each group was killed daily between 08.30 and 10.30 hours, changing the order each day, and the liver was rapidly removed, weighed and homogenized (Ultraturrax Polytron Mixer, Type PT 10-35). Two homogenates were prepared: one in $0.66 \mathrm{~mm}$-EDTA-saline ( $9 \mathrm{~g}$ sodium chloride/l) buffer (Schmidt et al. 1958) for the estimation of glucose-6-phosphate dehydrogenase activity and glycogen; the other in 5 mM-Tris, $250 \mathrm{~mm}$-saccharose buffer, $\mathrm{pH} 7.4$ (Beaufay et al. 1974), for measurement of liver protein and the other enzyme activities.

\section{Assays}

Hepatic glycogen was extracted according to Pfleiderer (1963) and the resulting glucose assayed using Trinder's (1969) method.

- For reprints.

$\dagger$ Present address: Laboratoire de Biochimie Pharmacologique, E.R.A., CNRS No 698, Faculté des Sciences Pharmaceutiques et Biologiques, 7 rue Albert Lebrun, 54000 Nancy, France. 
Table 1. Effect on liver proteins and glycogen of giving rats a diet containing alcohol (diet E) or an alcohol-free control diet (diet $C$ )

(Mean values with their standard errors for eight rats per group unless otherwise stated)

\begin{tabular}{|c|c|c|c|c|c|c|c|c|c|c|c|c|}
\hline \multirow{3}{*}{ Phenotype... } & \multicolumn{6}{|c|}{ Diet C } & \multicolumn{6}{|c|}{ Diet E } \\
\hline & \multicolumn{2}{|c|}{ Wistar } & \multicolumn{2}{|c|}{$\mathrm{Fal}-$} & \multicolumn{2}{|c|}{$f a / f a$} & \multicolumn{2}{|c|}{ Wistar } & \multicolumn{2}{|l|}{$F a /-$} & \multicolumn{2}{|c|}{$f a / f a$} \\
\hline & Mean & SEM & Mean & SEM & Mean & SEM & Mean & SEM & Mean & SEM & Mean & SEM \\
\hline $\begin{array}{l}\text { Protein } \\
\text { mg/g liver } \\
\text { g/liver }\end{array}$ & $\begin{array}{r}196.9 \\
2.00\end{array}$ & $\begin{array}{c}19 \cdot 1 \\
0 \cdot 19\end{array}$ & $\begin{array}{l}194 \cdot 1 \\
1.89^{\mathrm{a}}\end{array}$ & $\begin{array}{c}16.5 \\
0.11\end{array}$ & $\begin{array}{l}162-7 \\
3.07^{\mathrm{e}}\end{array}$ & $\begin{array}{c}11 \cdot 5 \\
0 \cdot 28\end{array}$ & $\begin{array}{r}226 \cdot 6 \\
2 \cdot 38\end{array}$ & $\begin{array}{c}15 \cdot 4 \\
0 \cdot 16\end{array}$ & $\begin{array}{l}212 \cdot 3 \\
1 \cdot 99^{a} \cdot b\end{array}$ & $\begin{array}{c}10 \cdot 1 \\
0 \cdot 13\end{array}$ & $\begin{array}{c}207 \cdot 5^{*}, \dagger \\
2 \cdot 87 \dagger\end{array}$ & $\begin{array}{c}19 \cdot 1 \\
0.22\end{array}$ \\
\hline $\begin{array}{l}\text { Glycogen } \\
\text { mg/g liver } \\
\text { mg/liver }\end{array}$ & $\begin{array}{r}58 \cdot 2 \\
655 \cdot 8\end{array}$ & $\begin{array}{r}6 \cdot 7 \\
104 \cdot 6\end{array}$ & $\begin{array}{r}50 \cdot 7 \\
551 \cdot 7\end{array}$ & $\begin{array}{r}8 \cdot 5 \\
89 \cdot 2\end{array}$ & $\begin{array}{c}47 \cdot 1^{\mathrm{e}} \\
971 \cdot 5\end{array}$ & $\begin{array}{r}6 \cdot 4 \\
200 \cdot 0\end{array}$ & $\begin{array}{r}30 \cdot 0^{*} \\
344 \cdot 1^{*}\end{array}$ & $\begin{array}{r}6 \cdot 3 \\
71 \cdot 7\end{array}$ & $\begin{array}{r}33 \cdot 7^{*} \\
345 \cdot 2^{*}\end{array}$ & $\begin{array}{r}5 \cdot 7 \\
69 \cdot 7\end{array}$ & $\begin{array}{c}37 \cdot 3^{c, *} \\
585 \cdot 2^{*}\end{array}$ & $\begin{array}{r}5 \cdot 4 \\
164 \cdot 0\end{array}$ \\
\hline
\end{tabular}

Values were significantly different (Student's $t$ test) $(P<0.05):{ }^{a} F a /-v \cdot f a / f a$ for the same diet, ${ }^{b} F a /-v$. Wistar for the same diet, " $f a / f a v$. Wistar for the same diet, * alcohol $v$. control for the same phenotype.

$+n 7$.

Hepatic proteins were assayed by the method of Lowry et al. (1951).

The hepatic enzymes were assayed using the following techniques: glycerol kinase $(E C$ 2.7. 1.30) was assayed by the method of Thorner \& Paulus (1973), G6PDH by the method of Löhr \& Waller (1963), $\gamma$-glutamyl transferase (EC 2.3.2.2; GGT) by the method of Szasz (1969), alcohol dehydrogenase $(E C 1.1 .1 .1 ; \mathrm{ADH})$ by the method of Sund \& Theorell (1963), glucose-6-phosphatase (EC 3.1.3.9; G6-phosphatase) by the method of Khodjet el Khil (1976). Transaminase activities were assayed as follows: hepatic and plasma glutamate-pyruvate transaminase $(E C$ 2.6.1.2; ALT) was assayed using Boehringer kit no. 124591 (Anon. 1972) and hepatic glutamate-oxaloacetate transaminase (EC 2.6.1.1; AST) using Boehringer kit no. 124443 (Anon. 1972).

\section{Statistics}

The results were compared using Student's $t$ test.

\section{RESULTS}

\section{Liver and blood biochemical indices}

Protein concentrations per $\mathrm{g}$ liver were comparable among the three phenotypes. However, the $f a / f a$ rats given diet $\mathrm{E}$ had a higher protein concentration than those given diet $\mathrm{C}$, and total liver protein was significantly higher for the $f a / f a$ rats than for the controls (Table 1).

Total liver glycogen was greater for the obese rats as compared with control rats for both diets. However, the obese rats had less glycogen per $\mathrm{g}$ liver than the control rats when given diet $\mathrm{C}$, but more glycogen when given diet $\mathrm{E}$. Alcohol significantly lowered the glycogen concentration ( $\mathrm{mg} / \mathrm{g}$ liver) and the total glycogen $(\mathrm{mg} /$ liver) for all phenotypes (Table 1 ).

Hepatic enzyme activities. Hepatic ADH activity was lower for the $\mathrm{Fa} /$ - rats than for the Wistar or $f a / f a$ rats, whether or not the diet contained alcohol (Table 2).

When diet $\mathrm{C}$ was given, the hepatic GGT activity per mg protein was lower for the $\mathrm{fa} / \mathrm{fa}$ rats than for the Wistar rats, but total liver activities were comparable among all three types of rat. Giving alcohol resulted in increased hepatic GGT activity both on a per mg protein and a total liver basis for $\mathrm{Fa} /$-and $\mathrm{fa} / \mathrm{fa}$ Zucker rats, but did not affect Wistar rats. 
Ethanol and liver lipogenesis in the Zucker rat

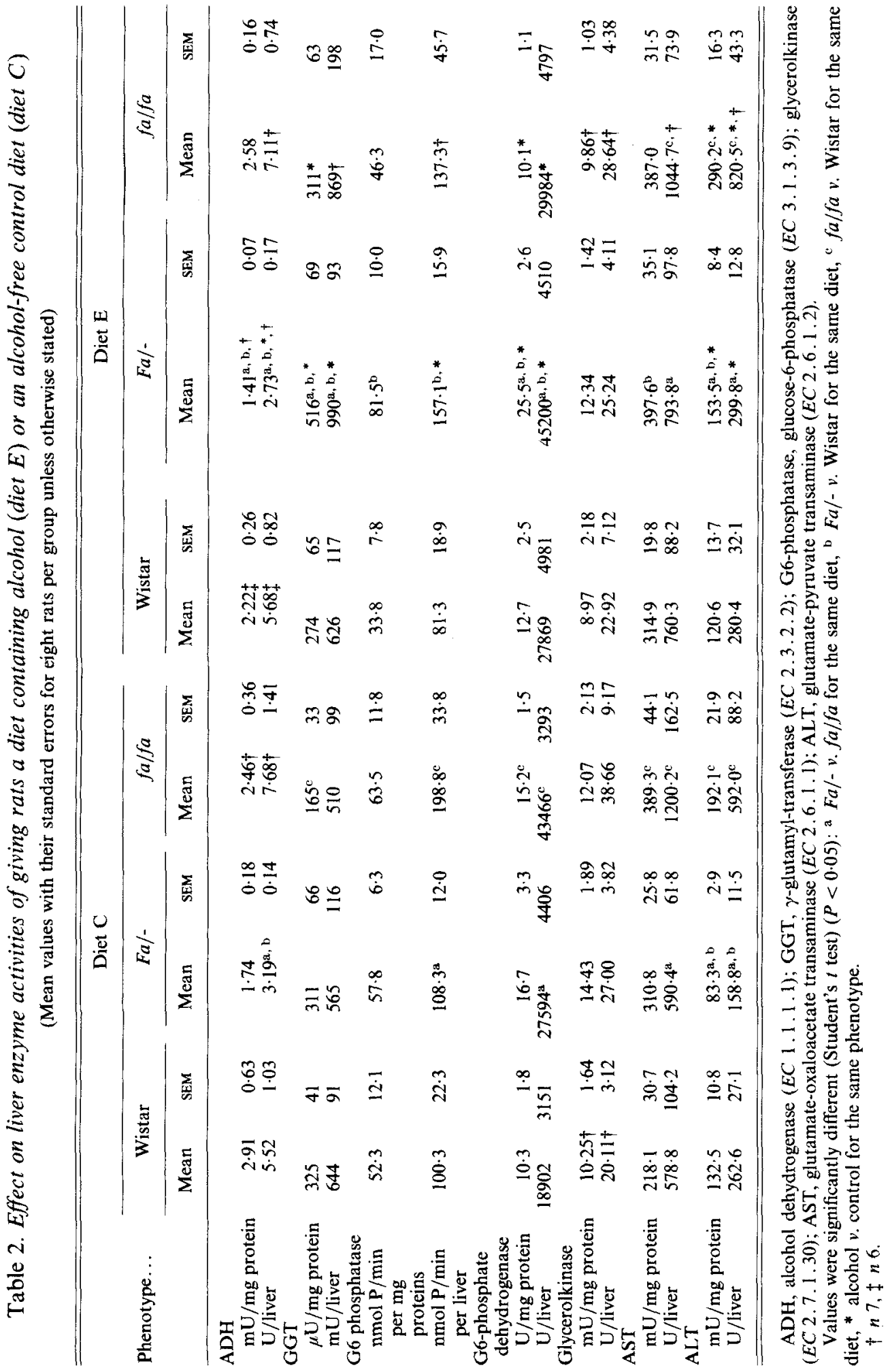


Table 3. Effect on plasma glutamate-pyruvate transaminase $(A L T)(E C 2.6 .1 .2)$ activity $(U / l)$ of giving rats a diet containing alcohol (diet $E$ ) or an alcohol-free control diet (diet $C$ ) (Mean values with their standard errors for eight rats per group unless otherwise stated)

\begin{tabular}{|c|c|c|c|c|c|c|c|c|c|c|c|c|}
\hline \multirow{3}{*}{$\begin{array}{c}\text { Phenotype... } \\
\text { Week }\end{array}$} & \multicolumn{6}{|c|}{ Diet C } & \multicolumn{6}{|c|}{ Diet $E$} \\
\hline & \multicolumn{2}{|c|}{ Wistar } & \multicolumn{2}{|c|}{$\mathrm{Fa} /-$} & \multicolumn{2}{|c|}{$f a / f a$} & \multicolumn{2}{|c|}{ Wistar } & \multicolumn{2}{|l|}{$\mathrm{Fa} /-$} & \multicolumn{2}{|c|}{$f a / f a$} \\
\hline & Mean & SEM & Mean & SEM & Mean & SEM & Mean & SEM & Mean & SEM & Mean & SEM \\
\hline 0 & $32 \cdot 6$ & $3 \cdot 8$ & $41 \cdot 2^{\mathrm{a}}$ & 6.8 & $62 \cdot 0^{\mathrm{c}}$ & $3 \cdot 0$ & $39 \cdot 0$ & $3 \cdot 2$ & $42 \cdot 7^{\mathrm{a}}$ & $4 \cdot 3$ & $81 \cdot 4^{c}$ & $17 \cdot 3$ \\
\hline 2 & 34.0 & 3.7 & 37.5 & 3.5 & $22 \cdot 3 \dagger$ & $10 \cdot 6$ & $38 \cdot 6$ & $3 \cdot 8$ & $46.0 \dagger$ & $5 \cdot 3$ & $61 \cdot 3^{*}$ & 12.6 \\
\hline 4 & 35.08 & 3.0 & $52 \cdot 4 \pi$ & 11.8 & $96 \cdot 9^{c}, \S$ & $29 \cdot 7$ & $49 \cdot 1^{*}$ & $4 \cdot 2$ & $71 \cdot 8^{\mathrm{b}}, \ddagger 9$ & $10 \cdot 7$ & $95 \cdot 4 \|$ & $36 \cdot 2$ \\
\hline
\end{tabular}

Values were significantly different (Student's $t$ test) $(P<0 \cdot 05):{ }^{a} F a /-v$. $f a / f a$ for the same diet, ${ }^{\mathrm{b}} F a /-v$. Wistar for the same diet, ${ }^{c} f a / f a v$. Wistar for the same diet, * alcohol $v$. control for the same phenotype; for the same phenotypes on the same diet: $\dagger 0$ v. 2 weeks, $\ddagger 0 v .4$ weeks.

$\S n 7, \| n 6,9 n 5$.

G6-phosphatase activity per mg protein was comparable for all phenotypes and with both diets, except that there was an increase in the $\mathrm{Fa}$ - rats given diet $\mathrm{E}$. The total liver activity was higher in $\mathrm{Fa} /-$ rats given diet $\mathrm{E}$ than in those given diet $\mathrm{C}$, but reduced in Wistar and $\mathrm{fa} / \mathrm{fa}$ rats.

Hepatic G6PDH activity per $\mathrm{mg}$ protein was greater in $\mathrm{Fa} /$ - rats than in the other phenotypes on both diets. Expressed per total liver, the activity was highest for $f a / f a$ rats eating diet $\mathrm{C}$ and $\mathrm{Fa} /$ - rats given diet $\mathrm{E}$. Alcohol increased G6PDH activity in lean rats, but produced a fall in activity in obese rats.

Total hepatic glycerol kinase activity was greatest in $f a / f a$ rats, and diet $\mathrm{C}$ gave higher values than diet $\mathrm{E}$.

However expressed, hepatic AST activity was higher for $f a / f a$ rats than for lean animals, except for the $\mathrm{Fa}$ /- rats given diet $\mathrm{E}$ when expressed per $\mathrm{mg}$ protein.

Hepatic ALT activity was much greater in $f a / f a$ rats than in lean rats, particularly when diet $\mathrm{E}$ was given.

Plasma enzyme activities. Plasma GGT activities were very low or undetectable in all groups studied and have not been reported.

Plasma ALT activity, both before and after 4 weeks on the experiment, was highest for $f a / f a$ rats and lowest for the Wistar rats (Table 3 ).

\section{DISCUSSION}

Karsenty et al. (1985) have shown previously that the energy consumption of the rat did not vary during the 4 weeks and that diet $\mathrm{E}$ yielded energy intake levels that were significantly higher than those for $\operatorname{diet} \mathrm{C}$, for all three phenotypes. Although they lost weight when compared with the controls, the $f a / f a$ Zucker rats given diet $\mathrm{E}$ remained obese and their obesity evolved similarly for both diets. Liver steatosis (fatty infiltration and degeneration of the liver) and hyperlipidaemia were less aggravated with diet $\mathrm{E}$, in contrast to what was expected (Thomson et al. 1980). As liver steatosis depends on hepatic lipid synthesis rates, we have studied this factor in $f a / f a$ Zucker rats receiving diets $\mathrm{E}$ and $\mathrm{C}$, and this is the work reported here.

Liver steatosis is the usual effect of chronic alcohol intoxication (Baraona \& Lieber, 1979). 
Nonetheless, other authors who have incorporated alcohol in animals' diets have demonstrated inhibited hepatic lipogenesis for control (Long-Evans) rats (Savolainen et al. 1977; Winston \& Reitz, 1979). A possible explanation is that alcohol oxidation results in the formation of uncoupled NADH, the ATP necessary for hepatic acylglycerol biosynthesis is not produced and consequently hepatic lipogenesis is inhibited (Pirola \& Lieber, 1972).

Obesity is characterized by increased glycolysis and pyruvate levels (Belfiore, 1980; McCune et al. 1981). The rate of glycolysis depends on the glycogen concentration and hence ultimately on the rates of glycogen formation and hydrolysis. Hepatic glycogen contents, which are highest for $f a / f a$ rats (Triscari et al. 1979, 1980), decrease with alcohol. A similar decrease has been described for alcohol-intoxicated Wistar and Long-Evans rats (Savolainen et al. 1977; Kondrup et al. 1980). Thus, in the alcohol-intoxicated obese rats, greater utilization of glycogen is associated with decreased G6-phosphatase activity. Alcohol, therefore, induces a decrease in hepatic glycogen formation in $f a / f a$ rats. Since glucose6-phosphatase dehydrogenase activity in obese rats (which was greater per total liver than in lean rats) was lower when diet $\mathrm{E}$ was given, diet $\mathrm{E}$ decreased the rate of glycogen hydrolysis. The metabolic variations result in decreased glycolysis in $f a / f a$ rats given diet E.

The transaminases (particularly ALT) are involved in pyruvate formation (Belfiore, 1980). As others have found (Spydevold \& Greenbaum, 1978; Schirardin et al. 1979), hepatic and plasma ALT activities increased for the obese rats given diet $\mathrm{E}$. The results for AST activity are in agreement with the findings of Cederbaum (1980), who showed that alcohol has little influence on the transaminases. Comparable amounts of pyruvate were formed with both diets.

With a reduced rate of glycolysis and stable pyruvate concentration in $f a / f a$ rats given diet $\mathrm{E}$, compared with those given diet $\mathrm{C}$, either hepatic lipogenesis would be decreased or hepatic lipogenesis would be normal and the lipolysis substrate (hydrogen peroxide) would be utilized in the degradation of alcohol to acetaldehyde by the catalase pathway (Lazarow, 1978). This would lead to reduced synthesis of complex lipids (notably triacylglycerols). Indeed, in earlier work (Karsenty et al. 1985), hepatic triacylglycerol levels were found to be lower for the $f a / f a$ rats given diet E. Although it was not significant, the decrease in hepatic glycerol kinase activity for these rats given diet $\mathrm{E}$ supports this suggestion. These changes are, therefore, the reverse of those described for the normal rat (Nikkila \& Ojala, 1963; Joly et al. 1973; Lamb \& Fallon, 1974), for which ethanol increases both the quantity of glycerol kinase metabolites ( $\alpha$-glycerophosphate; Nikkila \& Ojala, 1963) and the activities of enzymes (such as glycerol kinase) implicated in glycero-lipid synthesis (glycerophosphate acyltransferase (EC 2.3 1 . 15; Joly et al. 1973) and phosphatidate phosphatase (EC 3.1.3.4; Lamb \& Fallon, 1974)). This suggests that for the normal rat the fatty degeneration of the liver due to alcohol could be linked to the activation of these enzymes.

The less severe fatty infiltration in the livers of $f a / f a$ rats given diet $\mathrm{E}$ could be due to reduced lipogenesis or to the increased lipolysis in the liver. The liver retains its detoxification properties: hepatic ADH activity in the obese rat was equal to or greater than that of lean rats and this was not affected by alcohol. Hepatic GGT activity in the obese rat was increased by alcohol, as it is in alcoholic man (Anon. 1980) and in Sprague-Dawley rats (Ratanasavanh et al. 1982), leading to a seriously affected liver.

Thus, liver steatosis in the $f a / f a$ rat would appear to have an endogenous origin, but the severity varies according to the nutritional environment. These preliminary results do not make clear whether the paradoxical decrease in liver steatosis in the obese rat given diet $\mathrm{E}$ is due to the alcohol itself or to the decreased carbohydrate concentration of the diet.

Since steatosis was less severe in $f a / f a$ Zucker rats given diet $\mathrm{E}$ than in those given diet 
$\mathrm{C}$, we conclude that ethanol is not an exacerbating factor in fatty infiltration under these conditions. A possible explanation is that the replacement of carbohydrates by ethanol $(36 \%$ of the total energy) leads to reduced hepatic lipogenesis or increased hepatic lipolysis.

The present study was supported by INSERM CRL no. 78.5.231.7.

\section{REFERENCES}

Anon. (1972). Zeitschrift für Klinische Chemie und Klinische Biochemie 10, 182-192.

Anon. (1980). Lancet ii, 1117-1118.

Baraona, E. \& Lieber, C. S. (1979). Journal of Lipid Research 20, 289-315.

Beaufay, H., Amar-Costesec, A., Feytmans, E., Thines-Sempoux, D., Wibo, M., Robi, M. \& Berthet, J. (1974). Journal of Cell Biology 61, 188-212.

Belfiore, F. (editor) (1980). Enzyme Regulation and Metabolic Diseases pp. 145-148. Basel: Karger.

Cederbaum, A. I. (1980). Mount Sinai Journal of Medicine 47, 317-328.

Joly, J. G., Feinman, L., Ishii, H. \& Lieber, C. S. (1973). Journal of Lipid Research 14, 337-343.

Karsenty, C., Chanussot, F., Ulmer, M. \& Debry. G. (1985). British Journal of Nutrition 54, 5-13.

Khodjet el Khil, R. (1976). Effets d'antiépileptiques et d'hypolipémiants sur le mệtabolisme hépatique de l'acide glucuronique. These d'Etat en Pharmacie, Nancy.

Kondrup, J., Bro, B., Dich, J., Grunnet, N. \& Thieden, H. I. D. (1980). Laboratory Investigation 43, $182-190$.

Lamb, R. G. \& Fallon, H. J. (1974). Biochimica Biophysica Acta 348, 179-188.

Lazarow, P. B. (1978). Journal of Biological Chemistry 253, 1522-1528.

Löhr, G. W. \& Waller, H. D. (1963). Methods of Enzymatic Analysis, pp. 744-751 [H. U. Bergmeyer, editor]. London and New York: Academic Press.

Lowry, O. H., Rosebrough, N. J., Farr, A. L. \& Randall, R. J. (1951). Journal of Biological Chemistry 193, 265-275.

McCune, S. A., Durant, P. J., Jenkins, P. A. \& Harris, R. A. (1981). Metabolism 30, 1170-1178.

Nikkila, E. A. \& Ojala, K. (1963). Proceedings of the Society for Experimental Biology and Medicine 113, 814-817.

Pfleiderer, G. (1963). Methods of Enzymatic Analysis pp. 59-62 [H. U. Bergmeyer, editor]. London and New York: Academic Press.

Pirola, R. C. \& Lieber, C. S. (1972). Pharmacology 7, 185-196.

Ratanasavanh, D., Lahrichia, M., Galteau, M. M. \& Siest, G. (1982). Advances in Biochemical Pharmacology, 3rd ed., pp. 87-92 [G. Siest and C. Heusghem, editors]. Paris: Masson.

Savolainen, M. J., Hiltunen, J. K. \& Hassinen, I. E. (1977). Biochemical Journal 164, 169-177.

Schirardin, H., Bach, A., Schaeffer, A., Bauer, M. \& Weryha, A. (1979). Archives Internationales de Physiologie et de Biochimie 87, 275-289.

Schmidt, E., Schmidt, F. W. \& Wildhirt, E. (1958). Klinische Wochenschrift 36(4), 172-176.

Spydevold, S. O. \& Greenbaum, A. L. (1978). European Journal of Biochemistry 89, 329-339.

Sund, H.\& Theorell, H. (1963). The Enzymes, vol. VII, 2nd ed., pp. 25-83 [P. D. Boyer, H. Lardy and K. Myrback, editors]. London and New York: Academic Press.

Szasz, G. (1969). Clinical Chemistry 15, 124-136.

Thomson, A. D., Rae, S. A. \& Majumdar, S. K. (1980). Medical Consequences of Alcohol Abuse, pp. 113-116, [P. M. S. Clark and L. J. Kricka, editors]. New York: Ellis Horwood/John Wiley.

Thorner, J. W. \& Paulus, H. (1973). The Enzymes, vol. III, 3rd ed., p. 487 [P. D. Boyer, editor]. London and New York: Academic Press.

Trinder, P. (1969). Annals of Clinical Biochemistry 6, 24-27.

Triscari, J., Bryce, J. \& Sullivan, A. C. (1980). Metabolism 29, 377-385.

Triscari, J, Stern, J. S., Johnson, P. R. \& Sullivan, A. C. (1979). Metabolism 28, 183-189.

Winston, G. W. \& Reitz, R. C. (1979). Biochemical Pharmacology 28, 1249-1255. 